\title{
PENGARUH BUDAYA ORGANISASI DAN KONSEP DIRI TERHADAP PENGAMBILAN KEPUTUSAN KEPALA SEKOLAH DASAR NEGERI DI KECAMATAN JAGAKARSA
}

\author{
Rina Nurhidayati*
}

\begin{abstract}
This research is made to determine (1) the influence between organizational culture to decision making head of state primary school, (2) the influence self concept to decision making head of state primary school, and (3) the influence organizational culture to self concept head of state primary school. The research methodology that has been used was survey with path analysis technique in testing hypothesis. In this study, 54 head of state primary school have been used as a sample by using simple random sampling techniques (simple random sampling). This research conducted in Jagakarsa, South-Jakarta area. Based on the description of hypothesis test, the researches findings can be outlined as followed: (1) there is a positive influence between organizational culture to decision making head of state primary school, (2) there is a positive influence self concept to decision making head of state primary school, and (3) there is a positive influence organizational culture to self concept head of state primary school. The implication of this study is attempt of improving the decision making head of state primary school that can be done through improve organizational culture and self concept.
\end{abstract}

Keywords: decision making, self concept, organizational culture

\section{PENDAHULUAN}

Pendidikan merupakan keseluruhan yang terpadu dari sejumlah komponen yang saling berinteraksi dan melaksanakan fungsi-fungsi tertentu dalam rangka membantu anak didik agar menjadi manusia terdidik sesuai tujuan yang telah ditetapkan. Tujuan pendidikan berkaitan erat dengan hal yang ingin dicapai dalam program pendidikan. Oleh sebab itu, pendidikan nasional berkaitan erat dengan filsafat negara yang dianutnya.

Berdasarkan data dalam HDI (Human Development Index) pada tahun 2011 Indonesia meraih peringkat ke 111 dari 182 negara ke peringkat 124 dari 187 negara. HDI mengukur peringkat suatu negara dalam bidang pendidikan, kesehatan dan kesejahteraan ekonomi. Menurunnya peringkat Indonesia tersebut khususnya dalam bidang pendidikan menjadi salah satu faktor yang menyebabkan sekolah-sekolah Indonesia belum dapat bersaing dalam tataran global. Hal ini disampaikan oleh Sukro Muhab, ketua umum JSIT Indonesia.

Kepala sekolah sebagai pemimpin dalam sebuah lembaga memiliki andil yang besar dalam menentukan keberhasilan pendidikan. Dengan demikian kepala sekolah harus memiliki kompetensi seperti pengetahuan, sikap dan keterampilan pada dimensidimensi kompetensi kepribadian, manajerial, kewirausahaan, supervisi, dan sosial. Karena kompetensi-kompetensi tersebut sebagai penunjang keberhasilan kepala sekolah dalam usaha pencapaian tujuan dimana kepala sekolah harus dapat menguasai dan mampu melaksanakan tugas dengan baik.

Kepala sekolah selaku figur kunci dalam mendorong perkembangan dan kemajuan sekolah didalam tingkat sekolah, Kepala sekolah tidak hanya meningkatkan tanggung

\footnotetext{
* CEO Yayasan Pendidikan Nurul Aini
} 
jawab dan otoritasnya dalam program-program sekolah, kurikulum dan keputusan pribadi, tetapi juga memiliki tanggung jawab untuk meningkatkan akuntabilitas keberhasilan siswa dan programnya. Kepala sekolah harus pandai dalam memimpin kelompok dan pendelegasian tugas dan wewenang.

Inti dari kepemimpinan kepala sekolah tentunya pengambilan keputusan terhadap semua permasalahan di sekolah maupun perencanaan program. Tidak terlepas permasalahan yang menyangkut dengan guru. Seperti yang di kutip www.republika.co.id tanggal 28 Februari 2013 mengenai seorang guru yang menganiaya murid dengan penggaris besi.

Sulitnya pengambilan keputusan sangat dirasa dalam kasus ini. Dimana kepala sekolah harus bersikap bijak dan netral, tidak berpihak baik kepada guru ataupun orang tua murid. Seperti langkah yang diambil oleh kepala sekolah SDN 06 Srengsengsawah, kecamatan Jagakarsa, Widi Fatmah mengatakan, pihaknya tidak punya kewenangan untuk memutasi oknum guru terkait. Pertama kita akan panggil untuk klarifikasi, kedua diperingati, kalau tidak ada perubahan nanti kita surati Sudin Pendidikan Dasar.

Keberhasilan pengambilan keputusan kepala sekolah dalam upaya meningkatkan mutu sekolah tidak serta merta terjadi begitu saja, melainkan tentu saja dipacu oleh faktor-faktor lain yang koheren. Faktor- faktor yang potensial adalah budaya organisasi dan konsep diri. Berdasarkan uraian diatas peneliti tertarik untuk mengadakan penelitian dengan judul Pengaruh Budaya Organisasi dan Konsep Diri terhadap Pengambilan Keputusan Kepala Sekolah pada SD Negeri di Kecamatan Jagakarsa

\section{Pengambilan Keputusan}

Pengambilan keputusan menurut Steven McShane dan Mary Ann Von Glinow (2010:198) adalah "the conscious process of making process among alternatives with the intention of moving toward some desired state of affairs". Pernyataan di atas menjelaskan bahwa pengambilan keputusan adalah proses pengambilan beberapa alternatif untuk mencapai tujuan yang diinginkan. Dari berbagai macam alternatif tersebut kemudian akan dipilih solusi yang terbaik berdasarkan tujuan yang ingin dicapai

Menurut Jennifer M. George dan Gareth R. Jones (2005:471), secara umum pengambilan keputusan ialah "decision making can be defined as the process by which members of an organization choose a specific course of action to respond to opportunities and problems that confront them". Pengambilan keputusan dapat didefinisikan sebagai proses dimana anggota organisasi memilih aksi tertentu untuk merespon peluang dan masalah yang dihadapi mereka. Sebuah organisasi pastinya tidak luput dari sebuah masalah, sudah tentu dibutuhkan anggota organisasi yang perhatian akan kondisi organisasinya. Pada saat terjadi masalah, diharapkan dapat menemukan jalan keluar dari beberapa alternatif yang ada.

Pandangan lain tentang Pengambilan keputusan dikemukakan oleh Steven McShane dan Mary Ann Von Glinow (2010:198), menurut mereka "the conscious process of making process among alternatives with the intention of moving toward some desired state of affairs". Pernyataan di atas menjelaskan bahwa pengambilan keputusan adalah proses pengambilan beberapa alternatif untuk mencapai tujuan yang diinginkan. Dari berbagai macam alternatif tersebut kemudian akan dipilih solusi yang terbaik berdasarkan tujuan yang ingin dicapai.

Hal senada juga di ungkapkan oleh Jack Wood dan kawan-kawan (2013:467) mengenai pengambilan keputusan adalah "decision making is the process of identifying $a$ problem or opportunity and choosing among alternative courses of action". Pengambilan keputusan adalah proses mengidentifikasi masalah atau peluang dan memilih diantara 
beberapa alternatif tindakan. Pengambilan keputusan ini berkaitan dengan alternatif yang dihadapi individu (terutama pemecahan masalah) dan pilihan yang diambil individu terhadap alternatif yang ada. Setiap individu memiliki kondisi yang berbedabeda. Hal ini mempengaruhi atau ikut menentukan pilihan yang ada pada individu. Keputusan itu sendiri merupakan unsur kegiatan yang sangat vital. Jiwa kepemimpinan seseorang itu dapat diketahui dari kemampuan mengatasi masalah dan mengambil keputusan yang tepat. Keputusan yang tepat adalah keputusan yang berbobot dan dapat diterima bawahan. Ini biasanya merupakan keseimbangan antara disiplin yang harus ditegakkan dan sikap manusiawi terhadap bawahan. Keputusan yang demikian ini juga dinamakan keputusan yang mendasarkan diri pada human relations.

Pada saat terjadi masalah, diharapkan dapat menemukan jalan keluar dari beberapa alternatif yang ada. Hal senada juga di ungkapkan oleh Jack Wood dan kawan-kawan (2013:467) mengenai pengambilan keputusan adalah "decision making is the process of identifying a problem or opportunity and choosing among alternative courses of action". Pengambilan keputusan adalah proses mengidentifikasi masalah atau peluang dan memilih diantara beberapa alternatif tindakan. Pengambilan keputusan ini berkaitan dengan alternatif yang dihadapi individu (terutama pemecahan masalah) dan pilihan yang diambil individu terhadap alternatif yang ada. Setiap individu memiliki kondisi yang berbeda-beda. Hal ini mempengaruhi atau ikut menentukan pilihan yang ada pada individu. Keputusan itu sendiri merupakan unsur kegiatan yang sangat vital. Jiwa kepemimpinan seseorang itu dapat diketahui dari kemampuan mengatasi masalah dan mengambil keputusan yang tepat. Keputusan yang tepat adalah keputusan yang berbobot dan dapat diterima bawahan. Ini biasanya merupakan keseimbangan antara disiplin yang harus ditegakkan dan sikap manusiawi terhadap bawahan. Keputusan yang demikian ini juga dinamakan keputusan yang mendasarkan diri pada human relations.

Berdasarkan beberapa paparan di atas dapat disintesiskan pengambilan keputusan adalah proses mengidentifikasi masalah dari beberapa alternatif yang ada dengan tujuan untuk mendapatkan penyelesaian masalah yang terbaik dengan indikatorindikatornya adalah: 1) mengidentifikasi masalah, 2) membuat alternatif solusi, 3) mempertimbangkan alternatif solusi, 4) memilih solusi, 5) mengimplementasikan solusi, dan 6) mengevaluasi keputusan.

\section{Budaya Organisasi}

Secara umum, budaya organisasi dapat dipandang sebagai fenomena yang tidak tampak, seperti nilai, kepercayaan, asumsi, persepsi, norma-norma perilaku dan pola tingkah laku. Menurut John R. Schermerhorn, Jr. (2010:36) budaya organisasi adalah "organizational or corporate culture is the system of shared actions, values, and beliefs that develops within an organization and guides the behavior of its members". Budaya organisasi atau perusahaan adalah sistem tindakan bersama, nilai-nilai, dan keyakinan yang berkembang dalam suatu organisasi dan menjadi panduan perilaku anggotanya. Pengertian ini mengandung makna bahwa budaya organisasi harus menjadi dasar bagi anggota organisasi dalam melihat persoalan, berpikir, dan bertindak. Budaya dilihat sebagai suatu sifat informal yaitu cara hidup dan keunggulan dalam suatu organisasi yang mengikat bersama dan mempengaruhi apa yang mereka pikirkan tentang diri dan pekerjaannya.

Menurut Jennifer M. George dan Gareth R. Jones (2005:535) dalam buku Understanding and Managing Organizational Behavior menjelaskan mengenai budaya organisasi, yaitu: "organizational culture is the set of shared values, beliefs, and norms that 
influence the way employees think, feel, and behave toward each other and toward people outside the organization". Budaya organisasi adalah seperangkat nilai-nilai bersama, keyakinan, dan norma-norma yang mempengaruhi cara karyawan berpikir, merasa, dan berperilaku terhadap satu sama lain dan terhadap orang-orang di luar organisasi.

Beberapa pandangan mengenai budaya organisasi juga dijelaskan seperti berikut ini, menurut John W. Newstrom (2007:87) dalam buku Organizational Behavior, budaya organisasi adalah "organizational culture is the set of assumptions, beliefs, values, and norms that are shared by an organization's members". Budaya organisasi adalah seperangkat asumsi, keyakinan, nilai-nilai, dan norma-norma yang dianut oleh anggota organisasi. Menurut Stephen P. Robbins dan Mary Coulter (2012:52), budaya organisasi dapat didefinsikan sebagai berikut: "organizational culture has been described as the shared values, principles, traditions, and ways of doing things that influence the way organizational member act". Budaya organisasi adalah seperangkat asumsi, keyakinan, nilai-nilai, dan normanorma yang dianut oleh anggota organisasi.

Menurut Colquitt, Lepine dan Wesson (2009:456), budaya organisasi adalah "as the shared social knowledge within an organization regarding the rules, norms, and values that shape the attitudes and behaviors of its employees". Dari pengertian ini budaya organisasi dipandang sebagai upaya berbagi pengetahuan sosial melalui penghormatan organisasi terhadap aturan, norma dan nilai-nilai yang membentuk sikap dan perilaku setiap anggota organisasi.

Menurut Edward H. Shein didalam buku Luthans (2011:71) mengemukakan bahwa budaya organisasi merupakan "organizational culture defines it as a pattern of basic assumptions-invented, discovered, or developed by a given group as it learn to cope with its problems of external adaptation and internal integration-that has worked well enough to be considered valuable and, therefore, to be taught to new members as the correct way to perceive, think, and feel in relation to those problem". Menurut Schein, budaya organisasi merupakan pola asumsi dasar yang diciptakan, ditemukan atau dikembangkan oleh suatu kelompok karena berhadapan dengan penyesuaian lingkungan eksternal dan integrasi lingkungan internal yang telah berjalan cukup baik dan dianggap tepat sehingga dapat diajarkan kepada anggota baru sebagai cara yang tepat untuk memahami, memikirkan, dan merasakan ketika berhadapan dengan berbagai masalah. Pengertian ini mengandung makna bahwa budaya organisasi harus menjadi dasar bagi anggota organisasi dalam melihat persoalan, berpikir, dan bertindak. Budaya dilihat sebagai suatu sifat informal yaitu cara hidup dan keunggulan dalam suatu organisasi yang mengikat bersama dan mempengaruhi apa yang mereka pikirkan tentang diri dan pekerjaannya.

Berdasarkan paparan-paparan di atas dapat disintesiskan budaya organisasi adalah nilai, moral, keyakinan, aturan dan kebiasaan yang mempengaruhi perilaku anggota organisasi dan digunakan untuk beradaptasi dengan lingkungan kerja dengan indikator-indikatornya adalah: 1) kebiasaan nilai-nilai yang diajarkan, 2) kebiasaan di dalam pengambilan keputusan, 3) kebiasaan untuk kedisiplinan, 4) kebiasaan dalam memberikan apresiasi, dan 5) kebiasan saling tolong-menolong.

\section{Konsep Diri}

Dalam buku Social Psychology David G Myers (2005:41) mendefinisikan mengenai apa itu konsep diri. Menurutnya konsep diri adalah "self-concept is a person's answer to the question, "who am I?". Terkadang didalam hati manusia pernah menanyakan siapakah dirinya, apakah kelebihan ataupun kekurangan yang dimilikinya dan bagaimana diri kita di mata orang lain. Sedangkan konsep diri menurut Barry L Reece, 
Rhonda Brandt dan Karen F. Howie (2008:80) adalah "self concept is the bundle of facts, opinions, beliefs, and perceptions about yourself that are present in your life every moment of every day". Konsep diri dapat diartikan sebagai kumpulan pendapat, kenyataan, persepsi dan keyakinan terhadap diri sendiri disetiap harinya. Setiap manusia memang harus memiliki rasa yakin dan persepsi baik terhadap dirinya. Hidup akan berjalan sebagaimana seseorang memandang dirinya.

Di dalam buku Key Themes in Interpersonal Communication Culture, Identities and Performance karangan Anne Hill dan kawan-kawan (2010:41) menjabarkan tiga komponen yang membentuk konsep diri, yaitu: "an individual's self concept is commonly seen as having three main components: 1) the self-image, 2) self-esteem, and 3) the ideal self". Menurut Roy Berko dan kawan-kawan (2010:41) mengenai konsep diri adalah sebagai berikut: "self concept is the guiding factor in a person's actions. How a human being views oneself will determine most of his or her actions and choices in life. Essentially a person is going to choose what he or she feels he or she is worth". Roy Berko dan kawan-kawan berpendapat di dalam kehidupan konsep diri ini menjadi panduan manusia dalam menentukan setiap langkah dan pilihan. Pada saat seseorang sudah memiliki keyakinan dan kepercayaan diri yang kuat, maka didalam setiap pengambilan keputusan langkah hidupnya tidak akan ragu-ragu atau bimbang. Karena mereka sudah memikirkan langkah yang akan diambil kemudian kemungkinan-kemungkinan resiko yang akan terjadi

Seperti di jelaskan oleh Fred Luthans (2011:28) mengenai konsep diri, yaitu "people's attempts to understand themselves are called the self-concept in personality theory". Fred Luthans berpendapat setiap orang harus mengenal dan mengerti diri mereka sendiri. Mengenai "Siapa diri saya" dan "apa yang saya rasakan terhadap diri saya sendiri" kemudian secara harfiahnya akan menjelma sebagai afirmasi diri. Afirmasi diri yang positif akan menimbulkan energy yang positif juga dan sebaliknya afirmasi diri yang negatif akan membentuk energy yang negatif bagi diri sendiri. Ada baiknya setiap orang belajar untuk memiliki keyakinan,persepsi dan pendapat yang positif dengan memberikan "makanan" yang positif bagi jiwa melalui afirmasi diri.

Sedangkan Jack Wood dan kawan-kawan (2013:107) didalam buku Organisational Behaviour, Core Concepts and Application mengemukakan mengenai konsep diri bahwa "the self-concept Is the concept that individuals have of themselves as physical, social and spiritual or moral beings". Konsep diri adalah konsep yang dimiliki individu seperti fisik, sosial, keagamaan dan moral. Konsep diri terbentuk dari beberapa pengaruh, diantaranya adalah: keluarga, pendidikan, pengalaman dan lingkungan.

Steven McShane and Mary Ann Von Glinow (2010:43) mendefinisikan konsep diri sebagai berikut "self concept refers to An Individual's self belief and self evaluation". Konsep diri mengacu pada keyakinan seseorang dan evaluasi diri. Ini adalah "siapa aku?" dan "bagaimana saya merasa tentang diriku sendiri?" bahwa orang-orang bertanya pada diri sendiri dan yang memandu keputusan dan tindakan mereka.

Berdasarkan paparan-paparan di atas dapat disintesiskan konsep diri adalah penilaian atau pandangan seseorang terhadap dirinya sendiri yang mempengaruhi perilakunya, keputusan dan kebiasaan, serta menjadi panduan dalam setiap langkah dan pilihannya dengan indikator-indikatornya adalah (1) pandangan diri terhadap fisiknya, (2) pandangan diri terhadap psikologisnya, dan (3) pandangan diri terhadap sikapnya.

\section{METODE}


Penelitian ini menggunakan metode survey dengan teknik kausal. Penelitian ini akan menganalisis pengaruh satu variabel terhadap variable yang lain. Variabel yang dikaji terdiri dari dua macam, yakni variabel eksogen dan variabel endogen. Variabel endogen dalam penelitian ini adalah pengambilan keputusan kepala sekolah. Sedangkan variabel eksogen meliputi: budaya organisasi dan konsep diri. Penelitian ini dilaksanakan pada SD Negeri di kecamatan Jagakarsa, Jakarta Selatan dengan unit analisis Kepala Sekolah. Populasi penelitian adalah kepala sekolah pada SD Negeri di Kecamatan Jagakarsa kota Jakarta Selatan. Populasi terjangkaunya adalah sebanyak 62 kepala sekolah SD Negeri.

\section{HASIL DAN PEMBAHASAN}

Pengaruh Budaya Organisasi terhadap Pengambilan Keputusan

Hipotesis pertama penelitian ini adalah menduga bahwa budaya organisasi berpengaruh positif terhadap pengambilan keputusan. Berdasarkan hasil perhitungan analisis jalur, pengaruh langsung budaya organisasi terhadap pengambilan keputusan nilai koefisien jalur sebesar $\left(p_{31}\right)$ 0,421 dan koefisien korelasi $\left(r_{13}\right)$ sebesar 0,457 . Dengan demikian budaya organisasi berpengaruh langsung positif terhadap pengambilan keputusan. Steven McShane dan Mary Ann Von Glinow (2010:198) menjelaskan "the conscious process of making process among alternatives with the intention of moving toward some desired state of affairs". Pernyataan di atas menjelaskan bahwa pengambilan keputusan adalah proses pengambilan beberapa alternatif untuk mencapai tujuan yang diinginkan. Dari berbagai macam alternatif tersebut kemudian akan dipilih solusi yang terbaik berdasarkan tujuan yang ingin dicapai. Sedangkan John R. Schermerhorn, Jr. (2010:36) budaya organisasi adalah "organizational or corporate culture is the system of shared actions, values, and beliefs that develops within an organization and guides the behavior of its members". Budaya organisasi atau perusahaan adalah sistem tindakan bersama, nilai-nilai, dan keyakinan yang berkembang dalam suatu organisasi dan menjadi panduan perilaku anggotanya. Pengertian ini mengandung makna bahwa budaya organisasi harus menjadi dasar bagi anggota organisasi dalam melihat persoalan, berpikir, dan bertindak. Budaya dilihat sebagai suatu sifat informal yaitu cara hidup dan keunggulan dalam suatu organisasi yang mengikat bersama dan mempengaruhi apa yang mereka pikirkan tentang diri dan pekerjaannya.

Hasil ini sesuai dengan pandangan Stephen P. Robbins dan Mary COULTER (2012:180) bahwa "a manager's decision are influenced by culture in which she or he operates. An organizations's culture, especially a strong one, influences and constrains the way manager plan, organize, lead, and control". Keputusan seorang manajer itu dipengaruhi oleh budaya tempatnya bekerja. Dan budaya organisasi juga mempengaruhi cara manajer dalam perencanaan, mengkoordinasi, memimpin dan pengawasan.

\section{Pengaruh Konsep Diri terhadap Pengambilan Keputusan}

Hipotesa kedua penelitian ini adalah menduga bahwa konsep diri berpengaruh positif terhadap pengambilan keputusan. Berdasarkan hasil perhitungan analisis jalur, pengaruh langsung konsep diri terhadap pengambilan keputusan nilai koefisien jalur $\left(p_{21}\right)$ sebesar 0,4196 dan koefisien korelasi $\left(r_{23}\right)$ sebesar 0,624. Dengan demikian konsep diri berpengaruh langsung positif terhadap pengambilan keputusan. Anne Hill dan kawan-kawan (2010:41) menjabarkan tiga komponen yang membentuk konsep diri, yaitu: "an individual's self concept is commonly seen as having three main components: 1) the self-image, 2) self-esteem, and 3) the ideal self". Menurut Roy Berko dan kawan-kawan (2010:41) mengenai konsep diri adalah sebagai berikut: "self concept is the guiding factor 
in a person's actions. How a human being views oneself will determine most of his or her actions and choices in life. Essentially a person is going to choose what he or she feels he or she is worth". Roy Berko dan kawan-kawan berpendapat di dalam kehidupan konsep diri ini menjadi panduan manusia dalam menentukan setiap langkah dan pilihan.

Hasil penelitian di atas juga sejalan dengan pandangan Malikeh Beheshtifar (2012:6), bahwa "people with positive self-concepts behave more decisively. People can also make decisions with more certainty when they feel in control of the situation and feel sure enough of themselves through positive self-concepts to be unafraid of a commitment to their decisions. Once a decision is made, a person needs self-confidence to implement it". Orang dengan konsep diri positif berperilaku lebih tegas. Orang juga dapat membuat keputusan dengan pasti lebih ketika mereka merasa mengendalikan situasi dan merasa cukup yakin dari diri mereka sendiri melalui konsep diri yang positif menjadi tidak takut komitmen untuk keputusan mereka. Setelah keputusan dibuat, seseorang perlu kepercayaan diri untuk menerapkannya.

\section{Pengaruh Budaya Organisasi terhadap Konsep Diri}

Hipotesis ketiga penelitian ini adalah menduga bahwa budaya organisasi berpengaruh terhadap konsep diri. Berdasarkan hasil perhitungan analisis jalur, pengaruh langsung budaya organisasi terhadap konsep diri nilai koefisien jalur sebesar $\left(\mathrm{p}_{21}\right)$ dan koefisien korelasi $\left(\mathrm{r}_{12}\right)$ sebesar 0,617 . Dengan demikian budaya organisasi berpengaruh langsung positif terhadap konsep diri. John R. Schermerhorn, Jr. (2010:36) menjelaskan "organizational or corporate culture is the system of shared actions, values, and beliefs that develops within an organization and guides the behavior of its members". Budaya organisasi atau perusahaan adalah sistem tindakan bersama, nilai-nilai, dan keyakinan yang berkembang dalam suatu organisasi dan menjadi panduan perilaku anggotanya. Pengertian ini mengandung makna bahwa budaya organisasi harus menjadi dasar bagi anggota organisasi dalam melihat persoalan, berpikir, dan bertindak. Budaya dilihat sebagai suatu sifat informal yaitu cara hidup dan keunggulan dalam suatu organisasi yang mengikat bersama dan mempengaruhi apa yang mereka pikirkan tentang diri dan pekerjaannya.

Hasil penelitian di atas sejalan juga dengan pandangan Ronit Kark dan Dina Van Dijk (2007:502), bahwa "forces at various levels of analysis (e.g., personality traits, dyadic relationships, organizational culture) can influence the cognitive accessibility of a given selfconcept, leading to the activation of a particular identity level at a given point in time". Kekuatan di berbagai tingkat analisis (misalnya, karakter kepribadian, hubungan antar manusia dan budaya organisasi) dapat mempengaruhi aksesibilitas kognitif konsep diri yang diberikan, menyebabkan aktivasi dari tingkat identitas tertentu pada titik waktu tertentu.

\section{PENUTUP}

Kesimpulan: Berdasarkan analisis data, maka dapat disampaikan kesimpulan sebagai berikut: 1) Terdapat pengaruh langsung positif budaya organisasi terhadap pengambilan keputusan, 2) Terdapat pengaruh positif konsep diri terhadap pengambilan keputusan, dan 3) Terdapat pengaruh positif budaya organisasi terhadap konsep diri.

Saran: Berdasarkan kesimpulan di atas, dapat dikemukakan beberapa saran dapat dilaksanakan dalam rangka meningkatkan pengambilan keputusan kepala sekolah SD Negeri di Kecamatan Jagakarsa sebagai berikut: 1). Suku Dinas Pendidikan Kecamatan 
Jagakarsa, Jakarta Selatan dapat membuat pedoman yang baku dalam hal seleksi dan rekrutmen guru dan kepala sekolah, 2). Kedua, Suku Dinas Pendidikan Kecamatan Jagakarsa, Jakarta Selatan dapat mengembangkan dan sosialisasikan bagaimana cara membetuk konsep diri yang baik kepada seluruh kepala sekolah SD Negeri di Kecamatan Jagakarsa sehingga dengan begitu akan membentuk perilaku didalam pengambilan keputusan, dan 3). Ketiga, para peneliti terkait dengan hasil penelitian ini, agar melibatkan lebih banyak variabel prediktor yang diduga berpengaruh positif dengan pengambilan keputusan kepala sekolah. Selain itu selayaknya peneliti berikutnya dapat menggunakan juga sampel penelitian dari pimpinan sekolah dan instasi terkait.

\section{DAFTAR RUJUKAN}

Andika Primasiwi, "Mutu Pendidikan Indonesia Makin Mengkhawatirkan", http://www.suaramerdeka.com

George Jennifer M. dan Gareth R. Jones, Understanding and Managing Organizational Behavior, USA: Pearson Prentice Hall, 2005)

Hill, Anne, James Watson, Danny Rivers dan Mark Joyce, Key Themes in Interpersonal Communication: Culture, Identities and Performance, USA: Open University Press, 2007.

McShane, Steven dan Mary Ann Von Glinow, Organizational Behavior, New York: McGraw-Hill Irwin, 2010.

Myers, David G, Social Psychology, New York: Mc Graw Hill, 2005.

Malikeh Beheshtifar, "Positive Self-Concept: A Vital Factor to Overcome Career Indecision", Science Series Data Report, Vol 4, No. 4;Apr 2012, h. 6

Newstrom, John W, Organizational Behavior , New York: McGraw-Hill, 2007

Robbins, Stephen P dan Mary COULTER, Management, USA: Pearson Prentice Hall, 2012.

Republika, "Sadis, Guru Aniaya Murid dengan Penggaris Besi", Republika Online: http://www.republika.co.id.

Reece, Brandt B dan Howie K, Effective Human Relations Interpersonal and Organizational Applications, USA: South-Western Cengage Learning, 2008.

Ronit Kark dan Dina Van Dijk, Motivation to Lead, Motivation to Follow: "The Role of the Self Regulatory Focus in Leadership Processes", Academy of Management Review, Vol. 32 (2), 2007, h. 502 
Schermerhorn, John R, Organizational Behavior, USA: John Wiley \& Sons.Inc, 2010.

Wood, J.M et al, Organisational Behavior Core Concept and Applications, Australia: John Wiley \&Sons, 2013 